\title{
Correction to: European Handbook of Dermatological Treatments
}

\author{
Andreas D. Katsambas, Torello M. Lotti, \\ Clio Dessinioti, and Angelo Massimiliano D’Erme
}

\section{Correction to:}

\section{A.D. Katsambas et al. (eds.), European Handbook of Dermatological Treatments, https://doi.org/10.1007/978-3-662-45139-7}

The following corrections were made in Chapters 86 and 148:

1) On page 863 of Chapter 86 , the bulleted text "• Commercial preparations - Jacutin, Quellada lotion, Aphtiria" under the heading "Chlorinated Insecticides" was removed.

2) On page 1516 of Chapter 148, the bulleted text "• Scabicide (cream), Aphtiria (cream, powder) and Jacutin (emulsion, gel, cream) - $1 \%$ lindane (scabicide, pediculicide)" under the heading “Commercial Preparations" was removed. 